\title{
ADAPTING THE TSA TO MEASURE ECONOMIC CONTRIBUTION OF TOURISM IN SERBIA
}

\author{
Verka Jovanović, ${ }^{1, *}$, Slađana Vukasović ${ }^{2}$ \\ ${ }^{1}$ Singidunum University, Department for Postgraduate Studies \\ 32 Danijelova Street, Belgrade, Serbia \\ ${ }^{1}$ Singidunum University, PhD student \\ 32 Danijelova Street, Belgrade, Serbia
}

\begin{abstract}
:
The Tourism Satellite Account (TSA) enables estimating the direct contribution of tourism consumption to the national economy. The World Tourism Organization (UNWTO), the Organization for Economic Cooperation and Development (OECD) and the Statistical Office of the European Communities (Eurostat) have proposed the methodological framework for Tourism Satellite Account. The United Nations Statistical Commission (UNSC) approved its use in March 2000. Conceptually, TSA is compliant with other statistical frameworks such as the System of National Accounts (SNA) and the Balance of Payments (BOP) and it links tourism statistics and the SNA standard tables. The main objective of the TSA is to provide a better understanding of the scope and value of the tourism industry in Serbia, based on the figures and data that can be compared at an international level and whose reliability is very high since they are based on the quality of the official national statistics.
\end{abstract}

\section{Key words:}

tourism,

tourism satellite account (TSA),

SNA,

WTTC.

\section{INTRODUCTION}

There is a growing demand for consistent and comparable data for conducting an adequate economic policy of the country and timely decision making. For that purpose, tourism satellite account method has been used as the statistical method for determining the impact of tourism on economy and for providing details on the specific sectors (agriculture, tourism, health care) in the given country. In order to prepare satellite accounts, it is necessary to have specific and non-standard statistics.
For instance, the data on tourism demand are related to the activities of visitors and their share in the acquisition of goods and services. Moreover, information about tourism demand is related to a set of activities that serve the visitors. Satellite account is the extension of the System of National Accounts (SNA), which allows us to understand the size and the role of economic activity that is usually hidden behind them (Adžić, 2006). The System of National Accounts (SNA) represents a complete and harmoniously connected set of macroeconomic balance sheets and tables based on internationally 
agreed procedures, definitions and classifications (Mladenović et al., 2007). Therefore, SNA will not distinguish between newspapers bought by a local resident or a tourist, whereas in the satellite account, such purchases will be separated. Satellite accounts are linked to but distinct from the central system of the SNA (Virola et al., 2011). From this aspect, the tourism sector provides a comprehensive view of the state and its industry and calculates all the effects of tourism using well-known and proven TSA methodologies: RMF 2008 (UNWTO, 2010) in accordance with the international recommendations for tourism statistics (United Nations and WTO, 2010).

In order to understand the concept of satellite accounts, it is necessary to introduce a system of tables which are actually their integral part. Tourism satellite account is a system of ten tables derived from the supply and consumption of goods and services in the national accounts SNA 2008 (United Nations, 2009).

For the purpose of getting adequate information, it is necessary to do the following (Eurostat, 2010):

- to extract data related to tourism from the official national accounts,

- to distinguish spending by visitors that is tourism related from the one that is not tourism related,

- to analyze the value of goods purchased by visitors, including sales margins and the underlying value of the goods,

- to distinguish spending related to tourism for the purpose of vacation from the tourism buisness,

- to change the gross value of travel packages in the national accounts into net values required by TSA (the purpose is to separate the services by the organizer of travels as a component of packages).

\section{THE STRUCTURE OF TOURISM SATELLITE ACCOUNT}

The TSA is considered the most suitable method for assessing the contribution of tourism to the economy of a certain country (Wei et al., 2013). In order to develop the tourism satellite account (TSA), it is necessary to provide resources for its development including structured data, database development, development of the information exchange protocol, access to information for practical analysis and forecasting model (Vukasović, 2010). Tourism satellite account consists of a range of inter-related tables showing the size and distribution of different forms of tourism consumption in a country and its direct contribution to GDP, national value added, income, employment and other macroeconomic measures of national economy (UNWTO, 2013). Satellite account consists of the following 10 tables that comply with the international standards and TSA: RMF 2008 methodology (Eurostat, 2010):

1. Inbound tourism consumption,

2. Domestic tourism consumption,

3. Outbound tourism consumption,

4. Internal (internal) tourism consumption,

5. Production,

6. Domestic supply and internal tourism consumption,

7. Employment in the tourism industries,

8. Capital investment in tourism,

9. Tourism collective consumption,

10. The physical parameters (non-monetary indicators).

TSA tables are drawn pursuant to the national accounting system (SNA). They provide information specific to tourism industry and private/public consumption, investment expenditures and some useful information concerning tourist expenditures and tourism employment (Gül, 2013).

A minimum set of tables is required for the first phase of TSA. Tables 1-6 and 10 were used as a basis for the design of TSA tables (Šutalo et al., 2009). The above-mentioned tables should include a detailed overview of supply and consumption (expressed as consumption of goods and services by visitors) and activities they create, and their supporting units in the TSA. Tables can be expressed in current or constant prices, in local or foreign currencies. Tables 1 to 3 include categories of tourism expenditures while Table 4 contains an assessment of the total internal tourism consumption (travel expenses of domestic and foreign visitors increased by other components of tourism consumption).

In TSA Table 5 (Production account of tourism industries and all other industries), the rows represent commodity whereas the columns represent industries (Eurostat, 2009). Total Input is equal to the sum of intermediate consumption and value added. In the table below, numbers were used to explain the calculation methodology. 


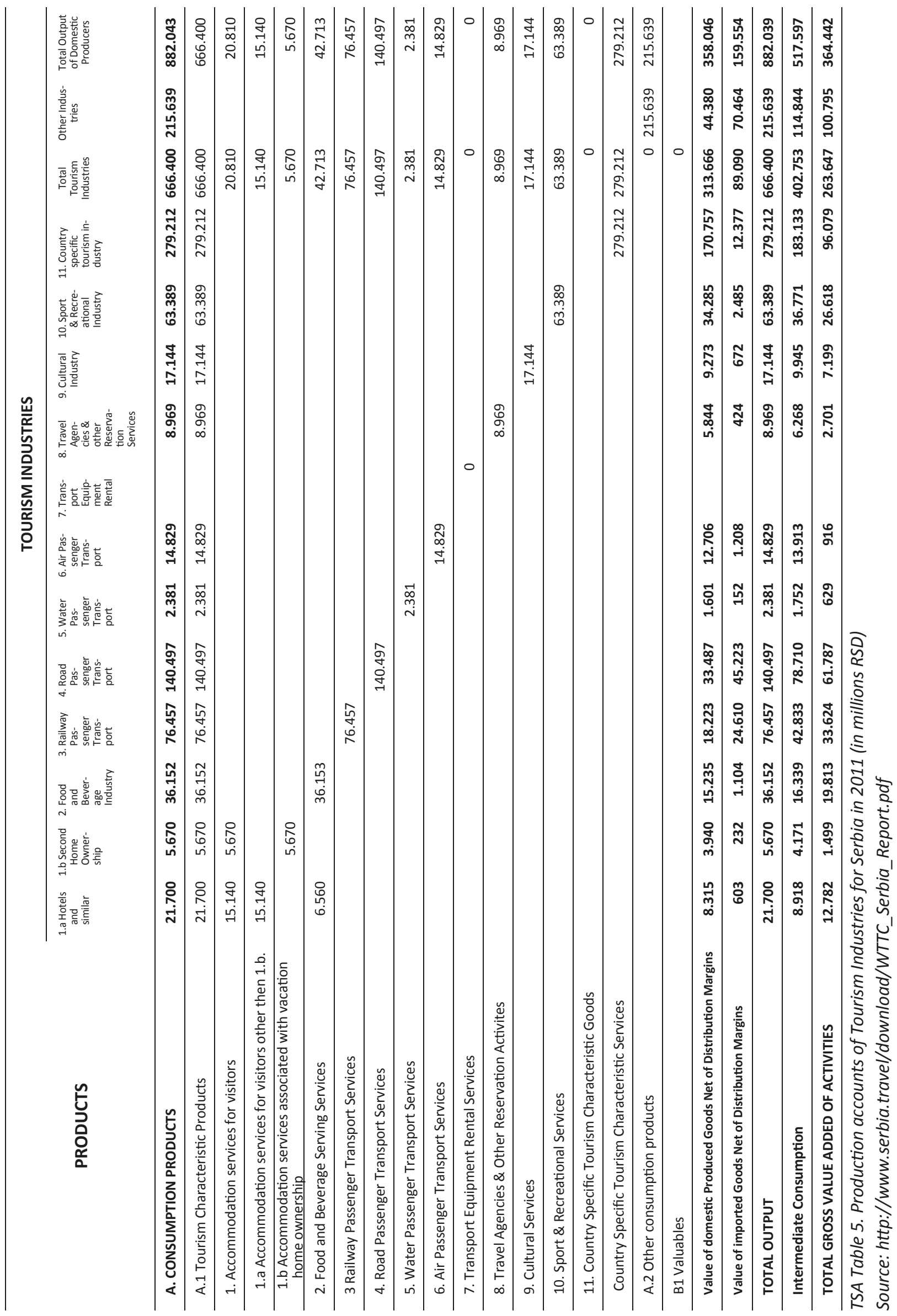


Given the fact that TSA is calculated based on the information from input-output tables, it turns out that total output (TO) is equal to total input (TI). The table is structured in accordance with the methods published in previous papers dealing with quantitative tourism analysis (Tadayuki, 2008).

$$
\mathrm{SP}=\mathrm{TO}=\mathrm{TI}=\mathrm{IC}+\mathrm{VA}
$$

The sum of all products (SP), generated by the hotels and accommodation sector is equal to total output (TO). Industry produces two different products: accommodation services for visitors and food and beverage services (TSA, Table 5)

$$
15.140+6.560=21.700
$$

Concurrently, the total output (TO) is equal to the total input (TI).Total input is the sum of intermediate consumption (IC) and value added (VA)

$$
21.700=8.918+12.782
$$

Since the total input equals total output according to the I-O method, we get that:

$$
\begin{gathered}
\text { Total input }=8.918+12.782=15.140+6.560= \\
\text { Total output. }
\end{gathered}
$$

TSA Table 5, which represents the production accounts of tourism industries and other industries, generates TSA Table 6 (Domestic supply and internal tourism consumption) along with TSA Table 4 (Internal tourism consumption).

Internal tourism consumption is correlated with domestic supply in Table 6. This table is the crucial part of the TSA as it establishes the gross value added attributable to visitor spending for each of the industries that serve the visitors. According to Frechtling (2009), without this table it is not possible to discuss the development of the TSA at all. The table enables us to determine the added value of tourism i.e. tourism GDP. All tables are mutually linked Table 1 and Table 2 generate Table 4 , whereas the data from Table 4 and Table 5 generate Table 6, as presented in Figure 1.

In order to provide structured data, it is necessary to carry out research for different TSA needs, such as research at the household level, border crossings, places that provide accommodation services, research of carriers, surveys related to popular tourist places, etc. For instance, research of household consumption could be performed using the survey where visitors need to record their expenses in a diary from the beginning till the end of their trip. Research at border crossings is suitable to estimate the costs of international visitors. Data exchange with neighboring countries and their research can be useful for getting more improved data. Conducting research at places providing accommodation services

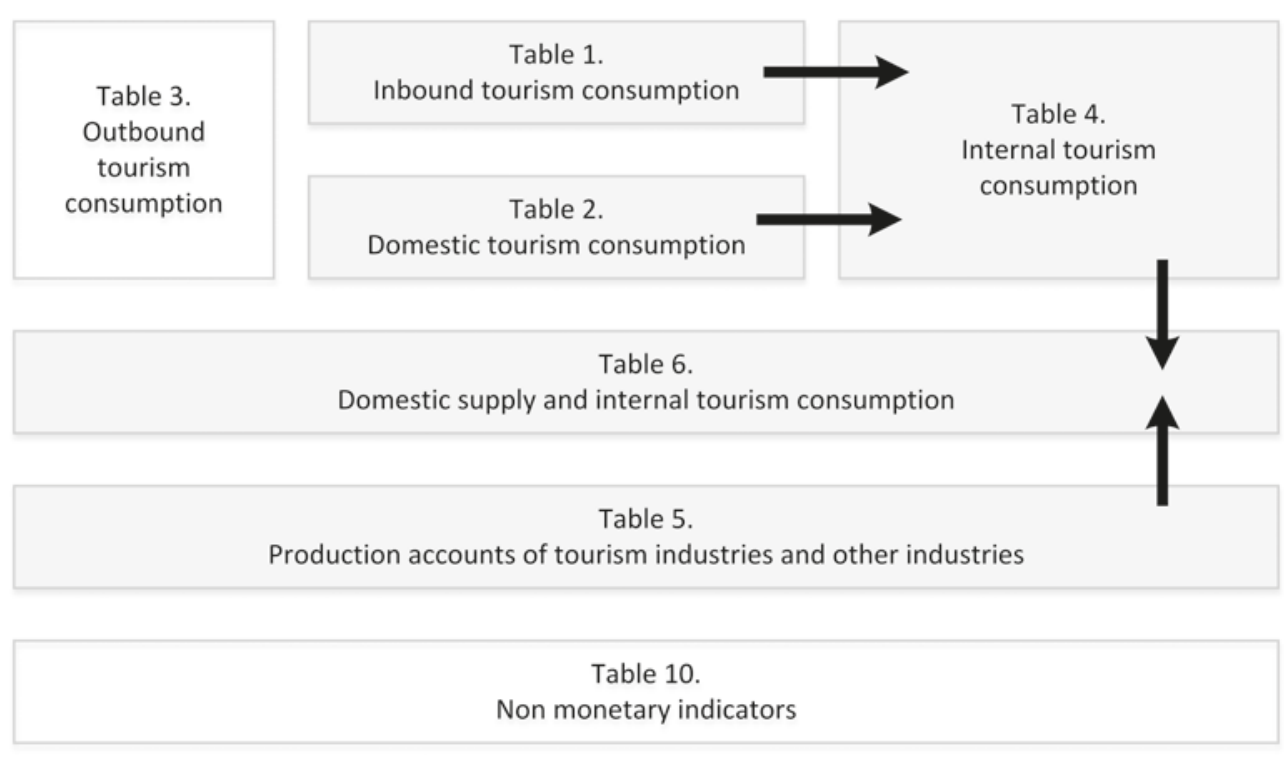

Figure 1: Tourism Satellite Account Tables

Source: http://unstats.un.org/unsd/publication/Seriesf/SeriesF_80rev1e.pdf. 
is not that complicated. It consists of interviewing guests in hotels and other accommodation facilities. Tourists are interviewed using the diary method or some other reliable method (questionnaires, interviews). Research related to the transport of passengers includes all transportation means, both domestic and international carriers. Such studies provide information on the type of connection; type of transport means used for the purpose of traveling and getting relevant information on whether the tourists are in transit or reside in a particular country. Studies in places where tourists are expected in large numbers, such as popular tourist attractions, coast, shopping malls, restaurants and cafes, duty-free shops, natural and cultural heritage monuments, public events, visiting events, ski resorts, passenger spending in transit, etc., would also be useful. Tables 5 and 6 provide data largely from the national accounts, I-O table, and the balance of payments. Such research has not still been implemented in Serbia, even though it represents the foundation for the development of tourism satellite accounts, and there is no developed input-output table, without which such analysis is impossible.

From an economic point of view, they represent an important part of the TSA because they gauge the overall socio-economic importance of tourism in the country. The main aggregates must be applicable within the industry so that they can be compared with other macroeconomic indicators. According to the proposal of the United Nations, UNWTO, Eurostat and OECD relative indicators for calculating the volume of the tourism industry include the following (UNWTO, 2010):

- Internal travel expenditures and internal tourism consumption,

- Gross value added of tourism activities,

- Tourism direct gross value added,

- Tourism direct gross domestic product (GDP).

Capital investments in tourism, tourism collective consumption, total tourism demand, employment in the tourism industry are the additional indicators. Within the scope of internal tourism expenditure and internal tourism consumption, tourism expenditures of incoming and domestic tourists are displayed, i.e. consumption as the widest scope of expenditures and other types of consumption of incoming and domestic tourists.

Gross value added of tourism activities is the sum of the total value added at basic prices of all economic entities in the tourism sector, regard- less of the extent to which the production i.e. value added of that sector is generated by the tourism spending.

Direct tourism value added covers the part of the tourism value-added and other activities generated by tourism demand and it is a measure of direct tourism contribution to the economy of the country. This unit does not cover the effects of other components of internal tourism demand (e.g. impact of gross or collective consumption).

Direct tourism gross domestic product is equal to the sum of value added tourism and other activities generated by internal tourism demand and net taxes on products (the difference between taxes and subsidies) included in the value of tourist expenditure at purchase prices. Tourism GDP measures only direct and internal effects of tourist spending, but not the entire tourism demand. It does not take into account indirect and induced effects of tourism. It is also known as the direct contribution of tourism and allows for international comparability (UNWTO, 2010).

\section{TSA MEASURMENT OF ECONOMIC CONTRIBUTION OF TOURISM IN SERBIA}

As Serbia still has no developed tourism satellite account, the World Travel \& Tourism Council represents a simulated TSA for Serbia (WTTC, 2013) and provides an assessment of the effects of tourism on the economy. WTTC identifies direct, indirect, and induced impacts on tourism. Direct contribution is mainly related to the economic activities of those entities that are directly related to tourists, such as hotels, travel agents, airlines and other means of transport excluding public transport services (Unković and Zečević, 2009). The indirect contribution is the result of capital investment, government spending, domestic purchases of goods and services from the sectors that are in direct contact with tourists - including, for example, the purchase of food or cleaning services in hotels, service and fuel supply or catering in the aircrafts and IT services of the passenger agencies, etc. (Dwyer et al., 2012). Induced contribution is the result of direct and indirect impacts on the tourism industry. Tourism satellite account is a unique tool available to policymakers in many countries to document the Direct Gross Domestic Product (GDP) and employment contributions of tourism to national economies (UNWTO, 2011). 


\section{The contribution of travel and tourism to the} gross domestic product of Serbia

The direct contribution of travel and tourism to gross domestic product in 2013 was 71 billion RSD or $1.9 \%$ of GDP. This figure is expected to grow by $6.6 \%$ during 2014, amounting to 76.6 billion RSD. The direct contribution of travel and tourism to GDP should grow by $4.9 \%$ annually on average, which would reach 124.0 billion or $2.4 \%$ of GDP by 2024 , as shown in Graph 1. In addition, the same graph shows that the total contribution of travel and tourism to GDP was 215.7 billion RSD in 2013. (5.7\% of GDP), while the growth by $6.2 \%$ is expected in 2014 , amounting to 229.1 billion, or $6.0 \%$ of GDP, with the growth at an average rate of $4.5 \%$ per annum by 2024, totaling 356.0 billion EUR, or $6.8 \%$ of GDP. According to the TSA methodology, the contribution of travel and tourism to GDP is calculated in Table 6 TSA: RMF 2008 (WTTC, 2014).

\section{The contribution of travel and tourism to employment in Serbia}

In 2013, travel and tourism directly generated 35,000 jobs i.e. $2.6 \%$ of the overall employment rate. This number is expected to increase by $6 \%$ this year, rising up to 37,000 employees or $2.7 \%$ of the total employment.
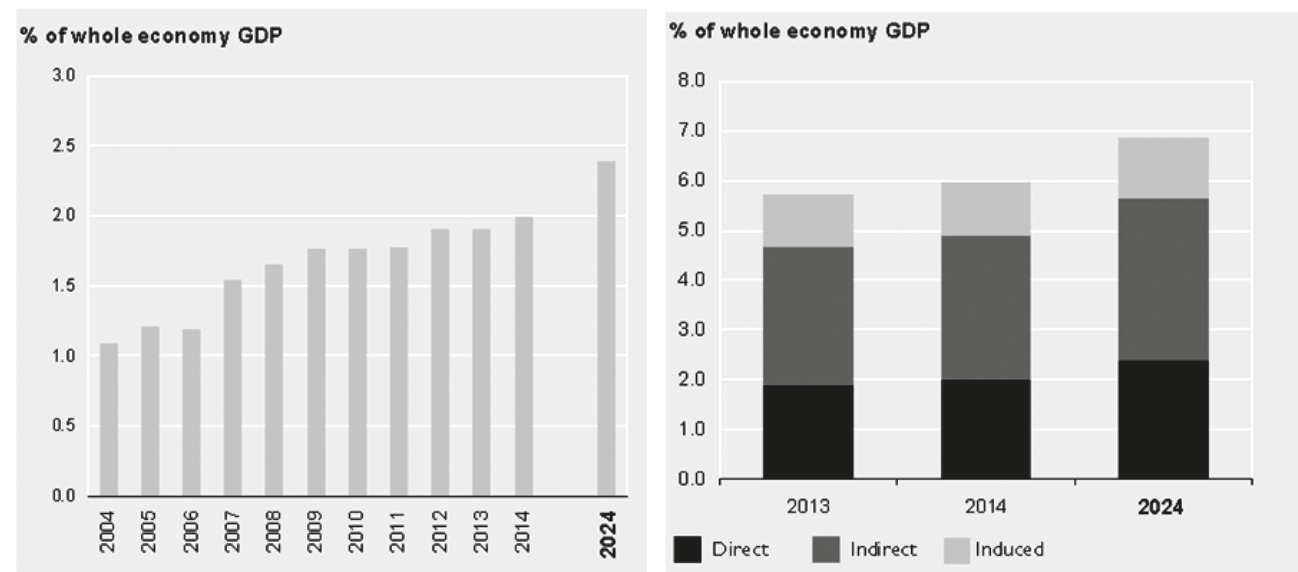

Graph 1: Direct and total contribution of travel and tourism to GDP in Serbia Source: http://www.wttc.org/site_media/uploads/downloads/serbia2014_1.pdf
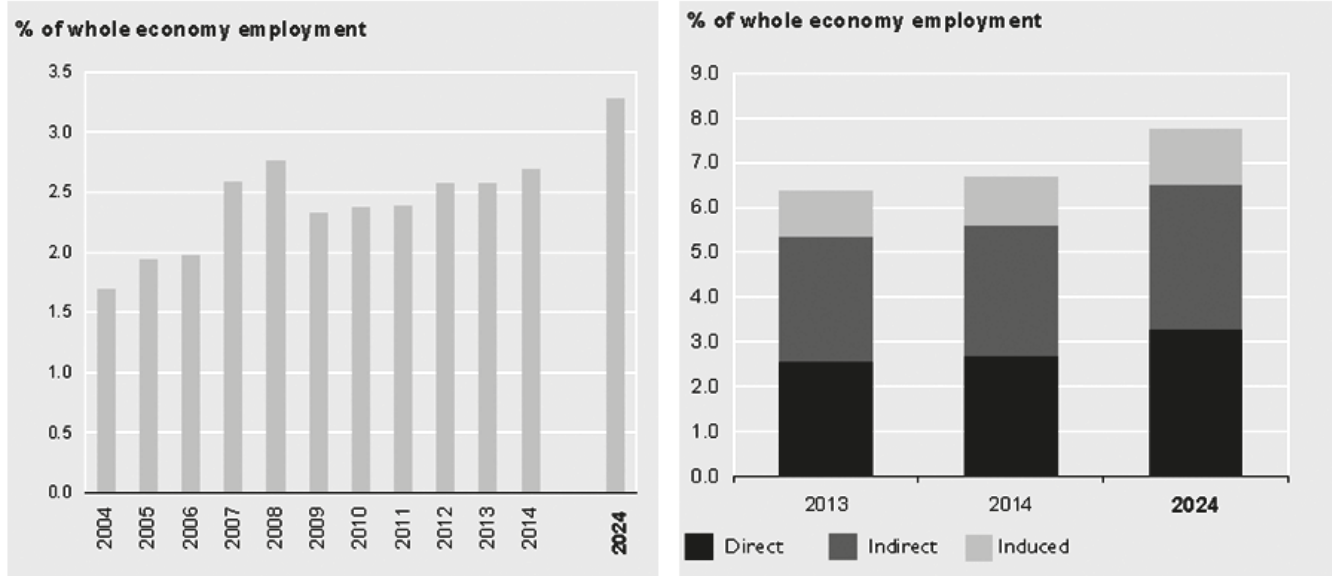

Graph 2. Direct and total contribution of travel and tourism to employment in Serbia Source: http://www.wttc.org/site_media/uploads/downloads/serbia2014_1.pdf 
This covers employees in hotels, travel agencies, airway and other passenger services companies (excluding public transport). It also involves the activities of the restaurant industry visited by tourists when they are on vacation. Travel and tourism industry is expected to provide 44,000 direct jobs by 2024 , followed by the average annual growth of $1.7 \%$ over the next ten years (see Graph 2). The same graph shows that the total contribution of travel and tourism to employment (including wider effects) was 86,500 jobs in 2013 , which accounts for $6.4 \%$ of the overall employment. It is anticipated that this number will grow to 91,500 employees in 2013, or $5.6 \%$, making up $6.7 \%$ of the overall employment. By 2024, travel and tourism could generate 103,000 jobs which makes up $7.7 \%$ of the workforce and an average annual increase of $1.2 \%$, during the ten-year period (WTTC, 2014). According to TSA methodology, employment is calculated in Table 7 TSA: RMF 2008. try will attract 880,000 foreign tourists. It is also anticipated that the arrival of international tourists will reach 1.291 million by 2014, and that they will spend 186.7 billion RSD, which is an average increase of $5.4 \%$ per annum (see Graph 3). This notion is consistent with the total cost of inbound international tourists in Table 1 TSA: RMF 2008. This table was made from special consumption generated by daily visitors, and overnight tourists (Eurostat, 2010). Tourism satellite account separates two categories. Thus, the assumption underlying the daily consumption of international visitors would be that they are not the residents of the country they come from, that they do not pay packages to tour operators in the country they are visiting, that they come primarily from neighboring countries and do not use the services typical for overnight tourists. These assumptions should be taken into account when calculating such forms of consumption. Unfortunately, the National Bureau of Statistics in Serbia still has
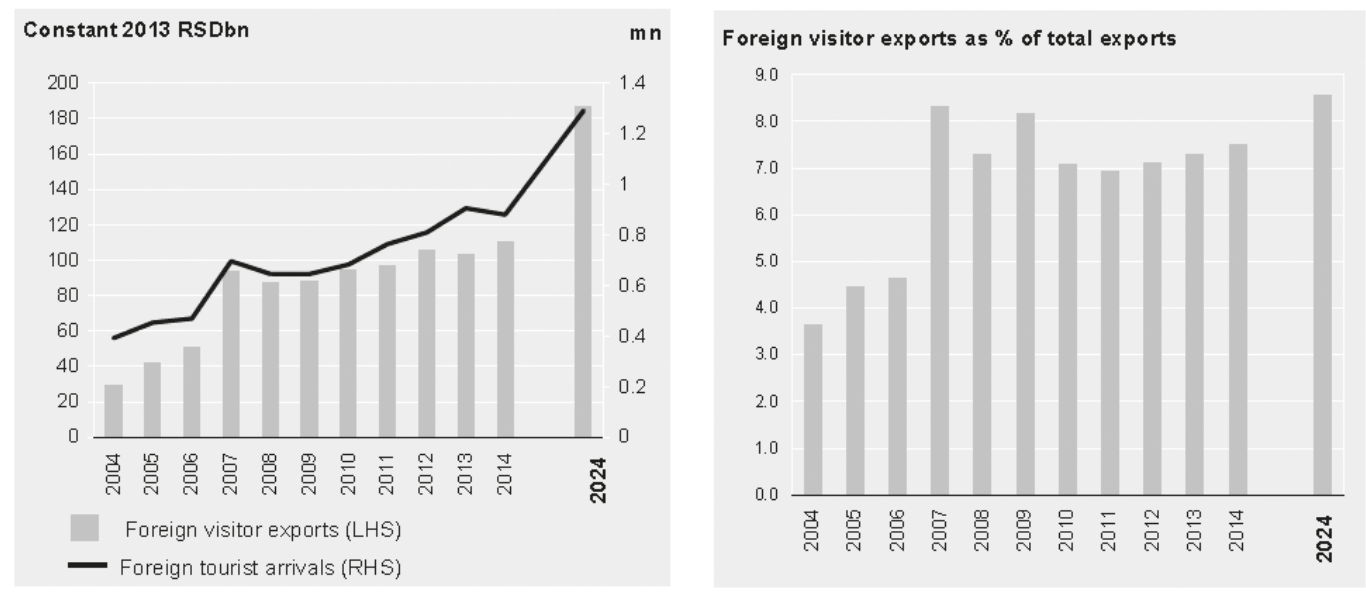

Graph 3. Visitor exports and international visitor arrivals in Serbia

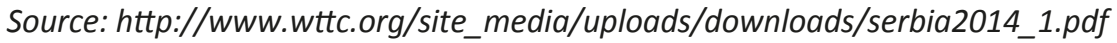

\section{Visitor exports ${ }^{1}$ - spending in Serbia by international travelers}

Consumption in the country by international travelers is a crucial component of the direct contribution of travel and tourism. In 2013, Serbia collected 102.9 billion RSD from international tourists. During 2014, it is projected that this number will increase by $7.4 \%$ with the expectation that the coun-

1 Visitor exports - spending within the country by international tourists for both business and leisure trips, including spending on transport no developed research on the consumption of daily visitors and overnight visitors.

\section{Capital investment in the tourism industry of Serbia}

Capital investment in Serbia includes the cost of capital of all sectors directly involved in tourism, including investment costs and other tourism related industries, such as new accommodation for visitors, equipment for transport of passengers, restaurants and accommodation facilities available within tourism sector. 

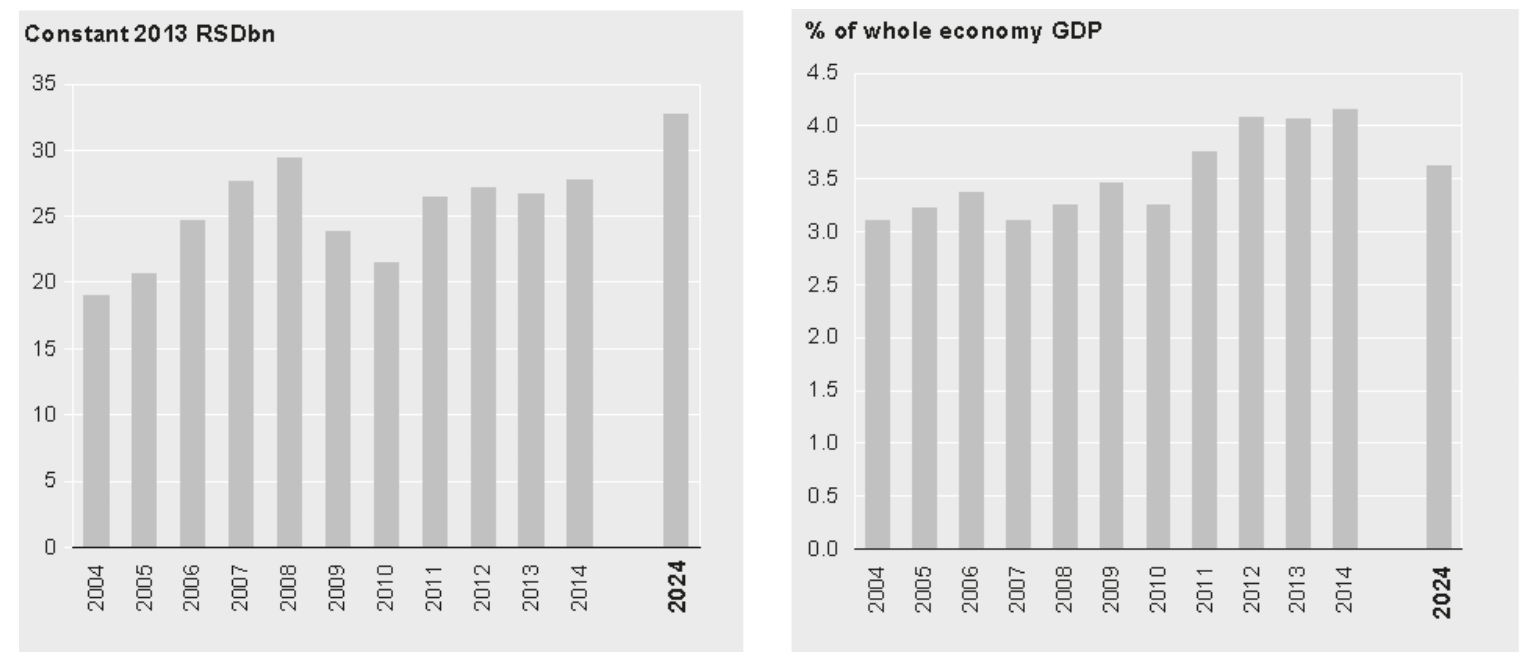

Graph 4. Capital investment in travel and tourism in Serbia

Source: http://www.wttc.org/site_media/uploads/downloads/serbia2014_1.pdf

It is expected that travel and tourism will attract capital investments worth 26.7 billion RSD, and that this amount will grow by $4.0 \%$ in 2014 , i.e. $1.6 \%$ on average annually over the next ten years, amounting to 32.6 billion RSD. The share of travel and tourism in the total national investment will drop from $4.2 \%$ in 2014 to $3.6 \%$ by 2024 (see Graph 4). These data are consistent with the Table 8 (Capital investment in tourism TSA: RMF 2008).

\section{CONCLUSION}

The success of the tourism industry is often measured by quantitative indicators, such as the number of arrivals and overnight stays, which are collected and produced by the national statistical organizations. As tourism is a very complex social and economic phenomenon, it is very difficult to measure it. Therefore, it is necessary to apply the appropriate calculation methodology such as TSA so as to estimate the volume of tourism industry. Over 60 countries worldwide have completely developed TSA (UNWTO, 2010). Unfortunately, Serbia still has no reliable, complete and structured data sources for the implementation of tourism satellite account. Therefore, besides basic research related to the number of overnight stays, number of arrivals of domestic and foreign tourists and research on travel agencies, it is necessary to conduct other types of research that would contribute to generating reliable data for the application of tourism satellite account. Moreover, it is quite significant to conduct research related to the consumption of tourists, both domestic and foreign, in the country and abroad, and provide all necessary data for the preparation of input-output tables on which the development of TSA tables is based and that are part of the national accounts. With respect to this, it is necessary to conduct research in Serbia that would monitor the number of daily visitors apart from tracking the number of overnight tourists.

Also, it is of great importance to choose the sectors that are directly related to tourists (hotels, airline companies, travel agencies, etc.) as well as those that are not directly related to tourists (restaurants, various shopping, public transportation, etc.). If we reduce tourism only to sectors that have a strong relationship with tourists, there is a good chance that we will underestimate the actual size of the tourism industry and vice versa, if we include all sectors that may be associated with tourists, we may overestimate the impact of tourism as an industry. Therefore, it is required to impose certain rules and criteria prescribed in the methodology of TSA RMF: 2008 while formulating groups of industrial sectors that provide services to tourists. It is also essential to provide the required resources including structured data, database development, development of a protocol for information exchange, access to information for practical analysis and model forecasting, since it is the only possible way to create a tourism satellite account - TSA. 


\section{REFERENCES}

Adžić, S. (2006). Privredni sistem i ekonomska politika. Subotica: Ekonomski fakultet. (in Serbian).

Dwyer, L., Forsyth, P., \& Dwyer, W. (2012). Tourism economics and policy. Bristol, UK: Channel View Publications.

Eurostat. (2009). Tourism satellite accounts in the European Union: Volume 3. Luxembourg: Office for Official Publications of the European Communities. Retrieved March 1, 2014, from http://epp.eurostat.ec.europa.eu/ cache/ITY_OFFPUB/KS-RA-09-021/EN/KS-RA-09021-EN.PDF.

Eurostat. (2010). European Implementation Manual on Tourism Satellite Accounts. Retrieved March 23, 2014, from http://ec.europa.eu/eurostat/ramon/statmanuals/files/TSA_EIM_EN.pdf.

Frechtling, D. (2009). The tourism satellite account: A primer. Annals of Tourism Research, 37(1), 136-153. doi: 10.1016/j.annals.2009.08.003.

Frechtling, D. (2011). Exploring the Full Economic Impact of Tourism Policy Making: Extending the Use of the Tourism Satellite Account through Macroeconomic Analysis Tools. Retrieved March 10, 2014, from http:// dtxtq4w60xqpw.cloudfront.net/sites/all/files/unwto_ paper_t20_france.pdf.

Gül, H. (2013). Economic impact of an increase in the foreign tourism receipts: A SAM - based income multiplier analysis for Turkey. Advances in Hospitality and Tourism Research, 11(1), 17-36.

Mladenović, D., Đolević, V., \& Šoškić, D. (2007). Ekonomska statistika. Beograd: Centar za izdavačku delatnost Ekonomskog fakulteta. (in Serbian).

Šutalo, I., Ivandić, N., \& Marušić, Z. (2009). Ukupan doprinos turizma gospodarstvu Hrvatske: Input - Output model i satelitski račun turizma. Ekonomski pregled, 62 (5-6), 267-285. (in Croatian)

Tadayuki, H. (2008). Quantitative tourism industry analysis: Introduction to input-output, social accounting matrix modeling, and Tourism Satelitte Accounts. Oxford: Butterworth-Heinemann.

United Nations, \& World Tourism Organization. (2010). International recommendations for tourism statistics 2008. New York: United Nations.
United Nations. (2009). System of National Accounts 2008. New York: United Nations. Retrieved March 13, 2014, from http://unstats.un.org/unsd/nationalaccount/docs/ SNA2008.pdf.

United Nations. (2011). Tourism Satellite Account: Recommended Methodological Framework. Retrieved March 13, 2014, from http://unstats.un.org/unsd/publication/ Seriesf/SeriesF_80revle.pdf.

Unković, S., \& Zečević, B. (2009). Ekonomika turizma. Beograd: Centar za izdavačku delatnost Ekonomskog fakulteta. (in Serbian).

UNWTO. (2010). Positioning Tourism in Economic Policy: Evidence and Some Proposals. Retrieved March 13, 2014, from http://dtxtq4w60xqpw.cloudfront.net/ sites/all/files/pdf/t20_document.pdf.

UNWTO. (2010). TSA data around the world, worldwide summary. Retrieved March 1, 2014, from http://statistics.unwto.org/sites/all/files/pdf/tsa_data.pdf.

UNWTO. (2013). The Economic Impact of Tourism: Overview and Examples of Macroeconomic Analysis. Retrieved March 3, 2014, from http://s3-eu-west-1.amazonaws.com/staticunwto/IP_Economic_Impact.pdf.

Van de Steeg, A. M. (2009). Accounting for tourism: The Tourism Satellite Account (TSA) in perspective. The Hague: Statistics Netherlands.

Virola, R., Reyes, R., Polistico, F., \& Oliveros, A. (2011). Things Statisticians wanted to know about the Tourism Satellite Account but were afraid to ask. Retrieved March 3, 2014, from http://www.nscb.gov.ph/stats/ ptsa/Techpaper_PTSA.pdf.

Vukasović, S. (2010). Satelitski obračun turizma. Master rad, Univerzitet Singidunum, Beograd, Srbija. (in Serbian).

Wei, Ch., Shuib, A., Ramachand, S., \& Herman, S. (2013). Applicability of economic models in estimating tourism impacts. Journal of Applied Economics and Business, 1(4), 5-16.

WTTC. (2013). Serbia travel \& tourism development potential 2011-2023. Retrieved March 23, 2014, from http://www.serbia.travel/download/WTTC_Serbia_Report.pdf

WTTC. (2014). Travel \& tourism economic impact 2014: Serbia. Retrieved March 23, 2014, from http://www. wttc.org/site_media/uploads/downloads/serbia2014_1. pdf. 


\section{PRIMENA SATELITSKOG RAČUNA TURIZMA ZA POTREBE MERENJA EKONOMSKOG DOPIRNOSA TURIZMA U SRBIJI}

\section{Rezime:}

Satelitski račun turizma (TSA) omogućava procenu direktnog doprinosa turističke potrošnje nacionalnoj ekonomiji. Svetska turistička organizacija (UNWTO), Organizacija za ekonomsku saradnju i razvoj (OECD) i Statistička kancelarija Evropske unije (Eurostat) predložile su metodološki okvir za izradu satelitskog računa turizma. Statistička komisija UN odobrila je njegovo korišćenje u martu 2000 godine. TSA pruža osnovnu konceptualnu doslednost sa ostalim statističkim okvirima poput Sistema nacionalnih računa (SNA) i platnog bilansa i predstavlja sponu između statistike turizma i SNA standardnih tabela. Glavni cilj primene satelitskog računa turizma jeste da se omogući bolje razumevanje razmera i vrednosti turističke industrije u Srbiji, zasnovane na brojkama i podacima koji se mogu porediti na međunarodnom nivou a čija je pouzdanost veoma velika $s$ obzirom da se zasnivaju na kvalitetu zvanične statistike.

\section{Ključne reči:}

turizam,

satelitski račun turizma (TSA), sistem nacionalnih računa (SNA),

Svetski savet za turizam i putovanja (WTTC).

Received: December 13th, 2013. Correction: Jun, 10th, 2014.

Accepted: Jun 24th, 2014. 